\title{
White-spot syndrome virus (WSSV) introduction into the Gulf of Mexico and Texas freshwater systems through imported, frozen bait-shrimp
}

\author{
K. W. Hasson ${ }^{1, *}$, Y. Fan $^{1}$, T. Reisinger ${ }^{2}$, J. Venuti ${ }^{1}$, P. W. Varner ${ }^{1}$ \\ ${ }^{1}$ Texas Veterinary Medical Diagnostic Laboratory, 1 Sippel Road, College Station, Texas 77845, USA \\ ${ }^{2}$ Texas Sea Grant/Cooperative Extension, 650 East Business Highway 77, San Benito, Texas 78586, USA
}

\begin{abstract}
We analysed 20 boxes of, frozen imported bait-shrimp (China: Parapenaeopsis sp. and Metapenaeopsis sp.) and 8 boxes of native, frozen bait-shrimp (Gulf of Mexico: Litopenaeus setiferus and Farfantepenaeus duorarum) by RT-PCR or PCR for Taura syndrome virus (TSV), yellowhead virus/gill-associated virus (YHV/GAV), white-spot syndrome virus (WSSV) and infectious hypodermal and hematopoietic necrosis virus (IHHNV). All 28 boxes of shrimp were negative for TSV, YHV/GAV and IHHNV; 2 boxes of imported bait-shrimp were WSSV-positive by 3 different PCR assays. Intramuscular injection of replicate groups of SPF (specific pathogen-free) L. vannamei juveniles with 2 different tissue homogenates prepared from the 2 WSSV-positive bait boxes resulted in $100 \%$ mortality of the test shrimp within 48 to $72 \mathrm{~h}$ post-injection. No mortality occurred among injected negative control groups. Histological and in situ hybridization analyses of 20 moribund treatment-shrimp demonstrated severe WSSV infections in each sample. Oral exposure of SPF L. vannamei postlarvae, PL (PL 25 to 30 stage $_{;} \sim 0.02 \mathrm{~g}$ ) to minced tissue prepared from the 2 WSSVpositive bait-lots did not induce infection, possibly because of an insufficient infectious dose and/or viral inactivation resulting from multiple freeze-thaw cycles of the bait-shrimp during PCR testing. Use of an electric drill and collection of drill-tailings (tissue from 20 to 30 shrimp) from frozen blocks of shrimp was successfully employed as an alternate tissue-sampling method without thawing. Our findings indicate that imported WSSV-infected bait shrimp, originating from China, are being sold in Texas for the purpose of sport fishing and represent a potential threat to freshwater and marine crustacean fisheries, as well as to coastal US shrimp farms.
\end{abstract}

KEY WORDS: White-spot syndrome virus · PCR · Histopathology · Bait-shrimp · Disease transmission · Biosecurity $\cdot$ Penaeid shrimp

\section{INTRODUCTION}

White-spot syndrome virus (WSSV) is the most economically important penaeid viral disease to impact global shrimp farms to date (Flegel \& Fegan 2002). An acute disease, WSSV infection often results in $100 \%$ mortality among affected penaeid populations within a 3 to $10 \mathrm{~d}$ period and the virus is known to infect shrimp of virtually all size classes (Lightner 1996, Flegel \& Fegan 2002). A member of the Nimaviridae (enveloped, ovoid, dsDNA virus), WSSV has spread from Asia throughout most of the Americas since its original recognition in China and Japan during 1992 and 1993, resulting in an ongoing panzootic that has cost the global shrimp farming industry billions of dollars in losses (Huang et al. 1994, Flegel \& Fegan 2002, OIE 2003, Lightner 2004). Because of its economic importance and designation as an OIE (Office International des Epizooties) notifiable pathogen, a diverse array of WSSV diagnostic techniques have been developed including histopathology, conventional and realtime PCR, antibody based tests, in situ hybridization, and dot-blot assays (Lightner 1996, 2004, OIE 2003). Histologically, WSSV induces the formation of large, 
variably staining intranuclear inclusion bodies within multiple target tissues that are readily identifiable by light microscopy and are considered pathognomonic for this disease (Lightner 1996).

The first recorded outbreak of WSSV in the western hemisphere occurred among wild-caught Gulf of Mexico (GOM) Litopenaeus setiferus shortly after they were stocked in a South Texas shrimp farm in 1995 (Lightner 1996). Between late 1995 through early 1997 , multiple WSSV epizootics were documented among feeder crayfish populations (Orconectes punctimanus and Procambarus sp.) at the National Zoo in Washington DC (Richman et al. 1997). Chang et al. (2001) demonstrated the presence of asymptomatic WSSV infections among wild Atlantic blue crabs Callinectes sapidus collected off the coasts of New York, New Jersey and Texas during 1997. Subsequent WSSV detection among indigenous GOM L. setiferus or Farafantepenaeus aztecus stocks occurred in 1997, 2001 and 2004 (pers. comm. P. Ostrowski, T. Varner, CEI 2004a). WSSV has also been reported for wild shrimp stocks in the Atlantic off South Carolina and Georgia, and was responsible for severe losses of farmed L. vannamei in South Carolina during 1997 (Prior et al. 2001, Chapman et al. 2004). The most recent outbreak of WSSV in the US occurred on an isolated L. vannamei farm in Kauai, Hawaii, during 2004 (CEI 2004a, Ostrowski 2004). Epizootics arising from a second OIE notifiable viral pathogen, Taura Syndrome virus (TSV), also occurred during the spring of 2004 in 5 South Texas L. vannamei farms (CEI 2004b, Ostrowski 2004). These recent outbreaks stimulated our interest in the source(s) of these viruses and their mode of introduction into the US.

The movement of shrimp viral pathogens between countries has mainly been attributed to the international sale of infected nauplii, postlarvae and broodstock (JSA 1997, Lightner 2002). Imported bait-shrimp, ship ballast-water, shrimp-farm effluent and shrimp packing-plant wastes have also been shown or implicated as potential virus sources (JSA 1997, Flegel \& Fegan 2002, Lightner 2002). It has been known for almost a decade that imported, frozen commodity shrimp are often infected with viruses such as WSSV, TSV, IHHNV (Infectious Hypodermal and Hematopoietic Necrosis virus) and YHV (Yellowhead virus) (Lightner et al. 1997, Nunan et al. 1998a, Durand et al. 2000, Prior et al. 2001). During 2004, a disease survey by PCR of grocery-store shrimp in Hawaii found that $73 \%$ were WSSV-positive and $82 \%$ were IHHNVpositive (Ostrowski 2004). While imported frozen commodity shrimp have been the focus of various studies, there has only been 1 report of virus-infected baitshrimp, whereby viable TSV was detected in imported bait shrimp purchased in South Carolina (Prior et al.
2001), but of unknown country of origin (C. Browdy, pers. comm.). In the current study we report the findings of a small disease-survey conducted on freshfrozen, indigenous GOM bait shrimp and fresh-frozen, imported wild bait shrimp from China that are being sold in Texas for sport fishing. Virus detection and infectivity was determined using PCR, histopathology, bioassays and in situ hybridization.

\section{MATERIALS AND METHODS}

Bait-shrimp. A total of 28 small rectangular boxes of frozen bait shrimp (227 $\mathrm{g}$ each) were purchased from inland and coastal grocery and bait stores in Texas (Table 1). The bait samples were numbered consecutively at the time of purchase and, hereafter, are referred to as bait box or box followed by a corresponding sample number. We purchased 22 bait boxes from 2 different sources near College Station, Texas, which consisted of 4 boxes of native Litopenaeus setiferus and 18 boxes of imported, wild-caught shrimp from China (as indicated by the product description label). Of the 18 boxes originating from China, 13 contained a Metapenaeopsis sp. and the remaining 5 contained a Parapenaeopsis sp. (Fig. 1). Identification of the imported shrimp from China was based on morphological characteristics utilizing shrimp taxonomy keys (Yu \& Chan 1986, Dore \& Frimodt 1987). We purchased 6 additional boxes of shrimp on the south Texas coast. These consisted of 4 different brands of bait containing solely Farafantepenaeus duorarum and/or a mixture of $F$. duorarum and $L$. setiferus from the GOM and 2 boxes of the same brand of imported wild Metapenaeopsis sp. from China that were originally found and purchased near College Station (Table 1, Fig. 1). The 28 boxes were maintained frozen until delivered to the laboratory and were then stored at $-80^{\circ} \mathrm{C}$ until processed.

Polymerase chain reaction (PCR). Tissue preparation: Individual boxes of shrimp were thawed 1 to 2 times and 30 to 60 pieces of pleopods from 30 individual shrimp were removed using sterile scissors; 30 pieces of pleopod tissue box $^{-1}$ ( $300 \mathrm{mg}$ total) were pooled for DNA extraction, and 30 pieces were similarly pooled for RNA extraction. Pooled tissue samples were prepared in this manner from the first 16 boxes analyzed. Multiple freeze - thaw cycles can inactivate some viruses (Parker \& Martel 2002), jeopardizing the potential of demonstrating virus viability through infectivity bioassays. To circumvent this possibility, a method was developed to sample frozen blocks of shrimp without thawing them and was applied to the last 12 boxes of imported bait shrimp from China that were purchased for this study. Briefly, an electric, vari- 
Table 1. Source, origin, identification and PCR results of frozen bait-shrimp samples purchased in Texas and analyzed for presence of WSSV, IHHNV, TSV and YHV/GAV. +: PCR-positive; -: PCR-negative

\begin{tabular}{|c|c|c|c|c|c|c|c|c|}
\hline \multirow{3}{*}{$\begin{array}{l}\text { Box } \\
\text { No. }\end{array}$} & \multirow{3}{*}{ Source } & \multirow{3}{*}{ Origin } & \multirow{3}{*}{ Shrimp } & \multicolumn{5}{|c|}{ PCR/RT-PCR results } \\
\hline & & & & \multicolumn{2}{|c|}{ WSSV } & \multirow{2}{*}{ IHHNV } & \multirow[t]{2}{*}{ TSV } & \multirow{2}{*}{ YHV/GAV } \\
\hline & & & & Nested & Single & & & \\
\hline 1 & Hearne, TX & China & Parapenaeopsis sp. & + & + & - & - & _- \\
\hline 2 & Hearne, TX & China & Parapenaeopsis sp. & - & - & _- & - & - \\
\hline 3 & Hearne, TX & China & Metapenaeopsis sp. & - & - & - & - & - \\
\hline 4 & Hearne, TX & China & Parapenaeopsis sp. & + & + & - & - & - \\
\hline 5 & Hearne, TX & China & Parapenaeopsis sp. & - & - & - & - & - \\
\hline 6 & Hearne, TX & China & Parapenaeopsis sp. & - & - & - & - & - \\
\hline 7 & Bryan, TX & GOM & Litopenaeus setfierus & - & - & - & - & - \\
\hline 8 & Bryan, TX & GOM & Litopenaeus setfierus & - & - & - & - & - \\
\hline 9 & Bryan, TX & GOM & Litopenaeus setfierus & - & - & - & - & - \\
\hline 10 & Bryan, TX & GOM & Litopenaeus setfierus & - & - & - & - & - \\
\hline 11 & Padre Island, TX & China & Metapenaeopsis sp. & - & - & - & - & - \\
\hline 12 & Padre Island, TX & China & Metapenaeopsis sp. & - & - & - & - & - \\
\hline 13 & Harlingen, TX & GOM & Farafantepenaeus duorarum & $n-$ & - & - & - & - \\
\hline 14 & Port O'Conner,TX & GOM & Farafantepenaeus duorarum & $n-$ & - & - & - & - \\
\hline \multirow[t]{2}{*}{15} & Padre Island, TX & GOM & Litopenaeus setfierus, & & & & & \\
\hline & & & Farafantepenaeus duorarum & $n-$ & - & - & - & - \\
\hline 16 & Padre Island, TX & GOM & Tails only & - & - & - & - & - \\
\hline $17-28$ & Hearne, TX & China & Metapenaeopsis sp. & - & - & - & - & - \\
\hline
\end{tabular}

able-speed, hand drill (Craftsmen) was set at medium speed and a sterile $1 / 8 "(3.175 \mathrm{~mm})$ drill bit was attached. The drill chuck was covered with aluminum foil to serve as a disposable splash guard, and a frozen block of shrimp was then perforated 10 to 15 times. Each frozen block consisted of shrimp stacked 2 to 3 deep, and it was estimated that each pass of the drill would penetrate $\sim 2$ individuals. The resulting frozen drill-tailings (tissue from $\sim 20$ to 30 shrimp) were transferred to a sterile, plastic, weigh boat and the frozen block of shrimp was returned to the freezer $\left(-80^{\circ} \mathrm{C}\right)$. Tailings containing portions of eye tissue (indicated by the presence of black pigment), were discarded, as this tissue contains PCR inhibitors (Lo et al. 1997). A sterile, $1000 \mu \mathrm{l}$ pipette tip was used to manually mix thawed tailings together, forming a homogeneous tissue paste. Approximately 300 to $350 \mathrm{mg}$ of the drill tailings was then homogenized for nucleic acid extraction as described in the next subsection. To prevent cross-contamination of the subsequent frozen block of shrimp to be sampled, the used aluminum foil chuck cover was discarded. The drill chuck was then rinsed, flamesterilized using $95 \%$ ethanol, a fresh sterile $1 / 8$ " bit was inserted and a new aluminum-foil splash guard was attached.

Nucleic acid extraction. DNA extraction of each bait box was conducted following the method of Loy et al. (1996) with slight modifications. Approximately 300 to $350 \mathrm{mg}$ of cut pleopod tissue or drill-tailings were placed in a $2 \mathrm{ml}$ FastPrep ${ }^{\circledR}$ tube (Q-Biogene/MP Biomedicals) together with a $1 / 4^{\prime \prime}(6.35 \mathrm{~mm})$ ceramic bead and $1000 \mu \mathrm{l}$ of lysis buffer (50 mM Tris, $20 \mathrm{mM}$
EDTA, $0.5 \%$ sodium docetyl sulfate, $\mathrm{pH}$ 8.0). Following homogenization in a FastPrep ${ }^{\circledR}$ shaker (Setting 6 for $40 \mathrm{~s}$ ) according to the manufacturer's instructions, the tubes were microcentrifuged at $650 \times g$ for 1 min to pel-



Fig. 1. Species of frozen bait-shrimp analyzed by PCR/RTPCR for presence of WSSV, IHHNV, TSV, and YHV/GAV. (A) Farafantepenaeus duorarum: Gulf of Mexico, US;

(B) Litopenaeus setiferus: Gulf of Mexico, US; (C) Parapenaeopsis sp.: China; (D) Metapenaeopsis sp.: China 
let debris, $300 \mu$ l of supernatant tube-1 transferred to a $1.5 \mathrm{ml}$ Eppendorf tube and $20 \mu \mathrm{l}$ Proteinase K $(20 \mathrm{mg}$ $\mathrm{ml}^{-1}$ ) were added. The tubes were incubated in a $65^{\circ} \mathrm{C}$ water bath for $1 \mathrm{~h}$ followed by enzyme inactivation via transfer of tubes into a boiling water bath (10 min). The tubes were then microcentrifuged (16 $000 \times g$ for $3 \mathrm{~min}$ ) and $100 \mu \mathrm{l}$ of supernatant were transferred to a Chromaspin TE-100 column followed by centrifugation at $700 \times g$ for 5 min according to the manufacturer's instructions (Clonetech Laboratories). The resulting DNA filtrate was then analyzed by PCR or stored for $<24 \mathrm{~h}$ at $4^{\circ} \mathrm{C}$ until assayed.

Homogenization of tissue for RNA extraction was conducted as described for DNA, substituting PBS (13.7 mM NaCl, $2.7 \mathrm{mM} \mathrm{KCl}, 10.1 \mathrm{mM} \mathrm{Na}{ }_{2} \mathrm{HPOO}_{4}$, $1.8 \mathrm{mM} \mathrm{KH}_{2} \mathrm{PO}_{4}, \mathrm{pH} \mathrm{7.4)}$ for the lysis buffer. RNA extraction was performed using TRIzol $^{\circledR}$ reagent according to the manufacturer's instructions (Invitrogen). Precipitated RNA was air-dried, suspended in $100 \mu$ of sterile, diethyl procarbonate-treated, nucleasefree water, and used immediately for RT-PCR or stored frozen $\left(-20^{\circ} \mathrm{C}\right)$ for $<24 \mathrm{~h}$ before analysis.

Nucleic acid amplification and detection: All 28 boxes of shrimp were individually tested by PCR and RT-PCR for the presence of WSSV, IHHNV, TSV and YHV/GAV (Gill-associated virus). Analysis for the presence of WSSV DNA was initially conducted using the nested PCR procedure of Lo et al. (1996). Confirmatory analyses for WSSV were then performed according to the single-step PCR methods of Kim et al. (1998) and Tapay et al. (1999). Detection of IHHNV DNA was done utilizing the PCR primers $77012 \mathrm{~F}$ and 77353R and protocol according to OIE (2003). Extracted RNA was used in the RT-PCR assays for the detection of TSV and YHV/GAV in accordance with the OIE-recommended methods of Nunan et al. (1998b) and Cowley et al. (2004), respectively. For each PCR assay, 1 negative control (water template) and 2 virus-positive controls (freshly extracted viral DNA or RNA and virus-specific PCR amplicons) were included for the purpose of quality control. Positivecontrol material was either collected by the authors or obtained from the University of Arizona, and consisted of a 2004 TSV isolate from Texas, 1994 WSSV isolate from China, 1993 YHV isolate from Thailand and a 2000 IHHNV isolate from Mexico. Amplification of shrimp beta-actin RNA and DNA of each sample was conducted separately to determine the nucleic acid quality of each sample, producing a $510 \mathrm{bp}$ amplicon using the primers and protocol of Dhar et al. (2002). PCR and RT-PCR was conducted in a $25 \mu \mathrm{l}$ reaction volume using the following template volumes: $2.5 \mu \mathrm{l}$ for all DNA viruses and beta-actin assays, $2.0 \mu \mathrm{l}$ for TSV and $3.0 \mu \mathrm{l}$ for YHV/GAV. Following amplification, the PCR products (10 $\mu$ l per sample) were pipetted into a $2 \%$ agarose gel submersed in $1 \times$ TBE buffer (tris borate EDTA, Promega) and electrophoresed (80 V, $45 \mathrm{~min})$. The gel was then stained with a $0.1 \%$ ethidium bromide solution (20 $\mathrm{min}$ ), the PCR bands visualized by UV transillumination, and photographed following standard methods (Sambrook et al. 1989).

Experimental shrimp. Specific pathogen-free (SPF) Litopenaeus vannamei juveniles $(\sim 80 ; 2.5$ to $4 \mathrm{~g}$ avg. wt) and postlarvae, PL ( 250; PL 5 to 10 stage; $0.003 \mathrm{~g}$ avg. wt) were generously donated by Shrimp Improvement Systems, Islamorada, Florida for this study. The juvenile population was used for 2 separate injection mediated bioassays and the postlarvae were reared to the PL 25 to 30 stage prior ( $0.02 \mathrm{~g}$ avg. wt) to use in an oral exposure bioassay. Upon arrival, juvenile shrimp were stocked and maintained in two 30 gal (114 l) glass aquaria containing static artificial seawater (Crystal Sea Marinemix ${ }^{\mathrm{TM}}$ ) at $31 \mathrm{ppt}, 26$ to $29^{\circ} \mathrm{C}$. Postlarvae were reared in a $30 \mathrm{gal}$ aquarium for $\sim 20 \mathrm{~d}$ under the same culture conditions. Each aquarium used throughout this study was aerated by a single airstone, and the tanks were covered to prevent escape of aerosols and shrimp. Individual siphons were assigned to each aquarium and 50 to $75 \%$ of the water volume was replaced every $48 \mathrm{~h}$ to minimize turbidity and maintain water quality.

Bioassay 1: Three 10 gal (38 l) aquaria were each stocked with 10 Litopenaeus vannamei (2.5 to $3 \mathrm{~g}$ avg. wt.). Following $24 \mathrm{~h}$ acclimation, 1 group of shrimp was intramuscularly injected with a homogenate prepared from the cephalothoraxic tissues (excluding the hepatopancreas) of 3 to $4 \mathrm{SPF}$ L. vannamei juveniles (negative control). The remaining 2 groups (treatments) were injected with a tissue homogenate prepared in like manner from Parapenaeopsis sp. (Bait Box 1) that were determined to be WSSV-positive by PCR. The inoculums were prepared and injected following the protocol of Hasson et al. (1995) with minor modifications. Briefly, 1 to $1.5 \mathrm{~g}$ of minced tissue was diluted 1:30 using sterile $2 \%$ saline, manually homogenized in a $50 \mathrm{ml}$ sterile, glass, tissue-grinder and the resulting homogenate centrifuged $(228 \times g, 10 \mathrm{~min})$ to pellet-tissue debris. The supernatant was filtered through a $0.2 \mu \mathrm{m}$ syringe filter (Acrodisc) and 25 to 30 $\mu \mathrm{l}$ were injected into the third tail segment of each shrimp $\left(10 \mu\right.$ filtrate $\left.\mathrm{g}^{-1}\right)$ using a $1 \mathrm{ml}$ tuberculin syringe. Following injection, each shrimp was returned to its respective aquarium and the population was monitored 3 times daily for clinical signs of disease over a period of $10 \mathrm{~d}$. All shrimp were maintained on a pelleted ration (Zeigler No. 4 PL pellet) fed once daily, ad lib.

Bioassay 2: The same experimental design and inoculum preparation as in Bioassay 1 was utilized, with the exception that the test shrimp had an average 
weight of 3 to $4 \mathrm{~g}$ and the 2 replicate treatment groups were intramuscularly injected with a tissue homogenate prepared from WSSV PCR-positive Parapenaeopsis sp. originating from Bait Box 4. The study was terminated $10 \mathrm{~d}$ post-injection. Observation times and feeding were identical to those in Bioassay 1.

Bioassay 3: Three 10 gal (38 l) aquaria were used, each stocked with 45 SPF Litopenaeus vannamei PL35-40 stage. All 3 groups were per os exposed to 1 of 3 minced, whole-shrimp tissue preparations following the methods of Hasson et al. (1999). One group was fed minced SPF L. vannamei tissue (negative control), the second group Parapenaeopsis sp. tissue from Bait Box 1 and the third Parapenaeopsis sp. tissue from Bait Box 4. We prepared 8 individual $0.09 \mathrm{~g}$ rations of minced tissue per treatment group, each equivalent to $10 \%$ of the biomass per aquarium, prior to initiating the study. The minced tissue rations were stored frozen $\left(-80^{\circ} \mathrm{C}\right)$ in Whirl-Pak ${ }^{\circledR}$ bags (Nasco) and thawed as needed. Each treatment group was fed its respective tissue ration once daily during the first 8 of the $21 \mathrm{~d}$ study. The shrimp were monitored 3 times daily for disease signs and, following termination of the per os treatments, fed a pelleted ration (Zeigler No. 4 PL pellet) ad lib once daily for the remaining $13 \mathrm{~d}$ of the study. Siphoning and water exchanges were conducted every $48 \mathrm{~h}$ as in the previous bioassays.

Histopathology and in situ hybridization. Following the methods of Bell \& Lightner (1988), 5 to 10 Litopenaeus vannamei test shrimp were preserved with Davidson's AFA (acetic acid, formalin, alcohol) fixative on Day 0 of each of the 3 bioassays, and analyzed by routine histology to insure their diseasefree status. When observed, moribund shrimp were preserved and analyzed in the same manner. Upon termination of a given bioassay, up to 5 shrimp per aquarium were sampled for histological analysis. Following routine tissue-processing, mid-sagittal sections of the cephalothorax and sixth tail segment, whole gill tissue and transverse sections of the first and third abdominal segments were paraffin-embedded, and 4 to $5 \mu \mathrm{m}$ sections were prepared on glass slides and stained with hematoxylin and eosin as described by Bell \& Lightner (1988). Confirmation of histological findings of WSSV was performed on 3 shrimp sections per treatment by in situ hybridization using a WSSV-specific digoxigenin labeled gene probe following the manufacturer's instructions (DiagXotics).

\section{RESULTS}

\section{Polymerase chain reaction (PCR)}

All 8 boxes of domestic bait shrimp and 18 of the 20 boxes of imported bait shrimp were revealed as negative for WSSV, YHV/GAV, TSV and IHHNV by RT-PCR or PCR; 2 boxes of imported shrimp containing Parapenaeopsis sp. (Boxes 1 and 4) were WSSV positive by nested and 2 separate single-step PCR procedures based on analyses of both pleopod samples (not shown) and drill tailing samples (Fig. 2). Positive and negative control samples included in each of the PCR assays functioned optimally. Beta-actin DNA amplification produced a strong $510 \mathrm{bp}$ band for each of the 28 samples (data not shown), indicating that the overall DNA within the samples was not degraded. Amplification of beta-actin RNA produced negative results for 18 samples and weak to moderate bands for the remaining 10 samples, suggesting that the RNA of the shrimp samples was completely or partially degraded when processed.

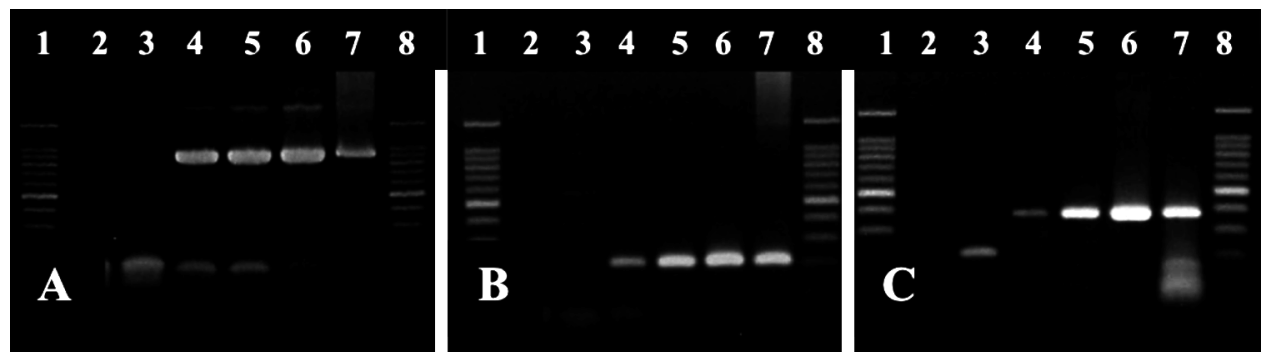

Fig. 2. WSSV electrophoretic band patterns from 3 separate PCR assays on frozen bait shrimp. Tissue samples of frozen SPF Litopenaeus vannamei and 2 separate boxes of frozen Parapenaeopsis sp. bait shrimp were collected by drill method (see 'Materials and methods') prior to DNA extraction and amplification. All 3 assays demonstrated that the 2 bait-shrimp samples were WSSV-positive. (A)WSSV nested-PCR (Lo et al. 1996) producing 941 bp product; (B) WSSV single-step PCR (Tapay et al. 1999) producing $211 \mathrm{bp}$ product; (C) WSSV single-step PCR (Kim et al. 1998) producing 365 bp product. Lanes 1 \& 8: 1 kb ladder; Lane 2: water template (negative control); Lane 3: SPF L. vannamei tissue (negative control); Lane 4: Parapenaeopsis sp. Bait Box 1; Lane 5: Parapenaeopsis sp. Bait Box 4; Lane 6: WSSV-positive L. vannamei tissue (positive control); Lane 7: WSSV-positive cDNA (positive control) 


\section{Bioassays}

Injection of replicate treatment groups of Litopenaeus vannamei juveniles with WSSV PCR-positive Parapenaeopsis sp. tissue homogenates induced 100\% mortality in the treatment shrimp within 48 to $72 \mathrm{~h}$ post-injection in both Bioassays 1 and 2 (Figs. 3 \& 4). Clinical signs of disease were observed in these animals within 18 and $48 \mathrm{~h}$ post-injection during Bioassays 1 and 2, respectively. Disease signs included lethargy, anorexia, and chromatophore expansion

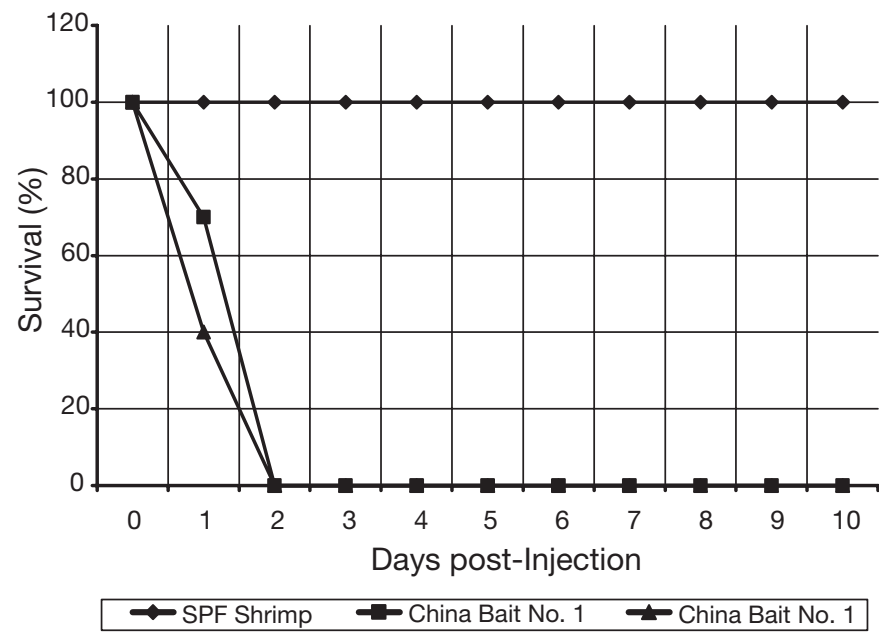

Fig. 3. Litopenaeus vannamei. Daily percentage survival of Bioassay 1, SPF juvenile shrimp following injection with either tissue homogenate prepared from Parapenaeopsis sp. bait-shrimp (Bait No. 1) or SPF L. vannamei (negative control). All shrimp injected with the bait-shrimp tissue homogenate died within $48 \mathrm{~h}$ post-injection

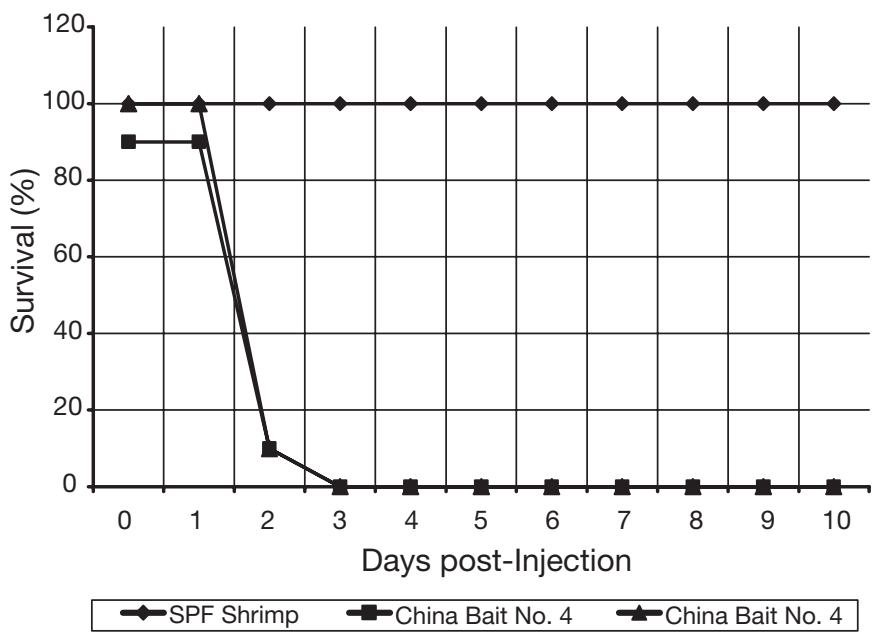

Fig. 4. Litopenaeus vannamei. Daily percentage survival of Bioassay 2 SPF juvenile shrimp following injection with either tissue homogenate prepared from Parapenaeopsis sp. baitshrimp (Bait No. 4) or SPF L. vannamei (negative control). All shrimp injected with the bait-shrimp tissue homogenate died within $72 \mathrm{~h}$ post-injection resulting in dark body coloration and reddening of both the uropods and antennae. No clinical signs of disease or mortality were observed among negative control shrimp during the $10 \mathrm{~d}$ that they were maintained post-injection in both bioassays.

Oral exposure of 2 separate groups of Litopenaeus vannamei stage PL 25 to 30 to minced tissue prepared from either WSSV-positive Box 1 or Box 4 Parapenaeopsis sp. tissue did not induce a WSSV epizootic during the $21 \mathrm{~d}$ study, as occurred in the injectionmediated bioassays. Upon termination of the study, percent survivals of the two treatment groups (Box 1 tissue $51 \%$, Box 4 tissue $69 \%$ ) were not significantly different from that of the negative control group (56\%) that had been exposed to SPF tissue. The chronic mortality that occurred among each of the 3 groups of test shrimp was attributed to cannibalism of recently molted shrimp.

\section{Histopathology and in situ hybridization}

Routine histological analysis of 5 to 10 shrimp samples collected on Day 0 of each of the 3 bioassays did not reveal any penaeid shrimp diseases by light microscopy. During Bioassays 1 and 2, 10 moribund shrimp were collected from the treatment groups injected with the imported, bait-shrimp homogenates. Severe multifocal to diffuse WSSV infections, characterized by large, variably staining, intranuclear inclusion bodies within the cuticular epithelium, hemal sinuses, connective tissues, antennal gland, lymphoid organ, heart and hematopoietic tissue, were revealed in all 20 shrimp by routine histology (Fig. 5). Lowgrade infection of the lining epithelium of the vas deferens was observed in 2 male shrimp. No viral infections were detected in the negative control shrimp upon termination of each of the 3 bioassays or within the orally exposed shrimp in Bioassay 3. In situ hybridization analysis of 3 moribund treatment-shrimp, collected during Bioassays 1 and 2, demonstrated strong WSSV-positive probe uptake by the intranuclear inclusion bodies in all 6 samples, corroborating the histological findings.

\section{DISCUSSION}

Past studies have demonstrated that imported frozen commodity shrimp sold for human consumption in the US frequently harbor infectious penaeid shrimp viruses (Lightner et al. 1997, Nunan et al. 1998a, Durand et al. 2000, Ostrowski 2004), and a single study in South Carolina identified TSV in frozen bait shrimp of indeterminate origin (Prior et al. 2001). The multiple 


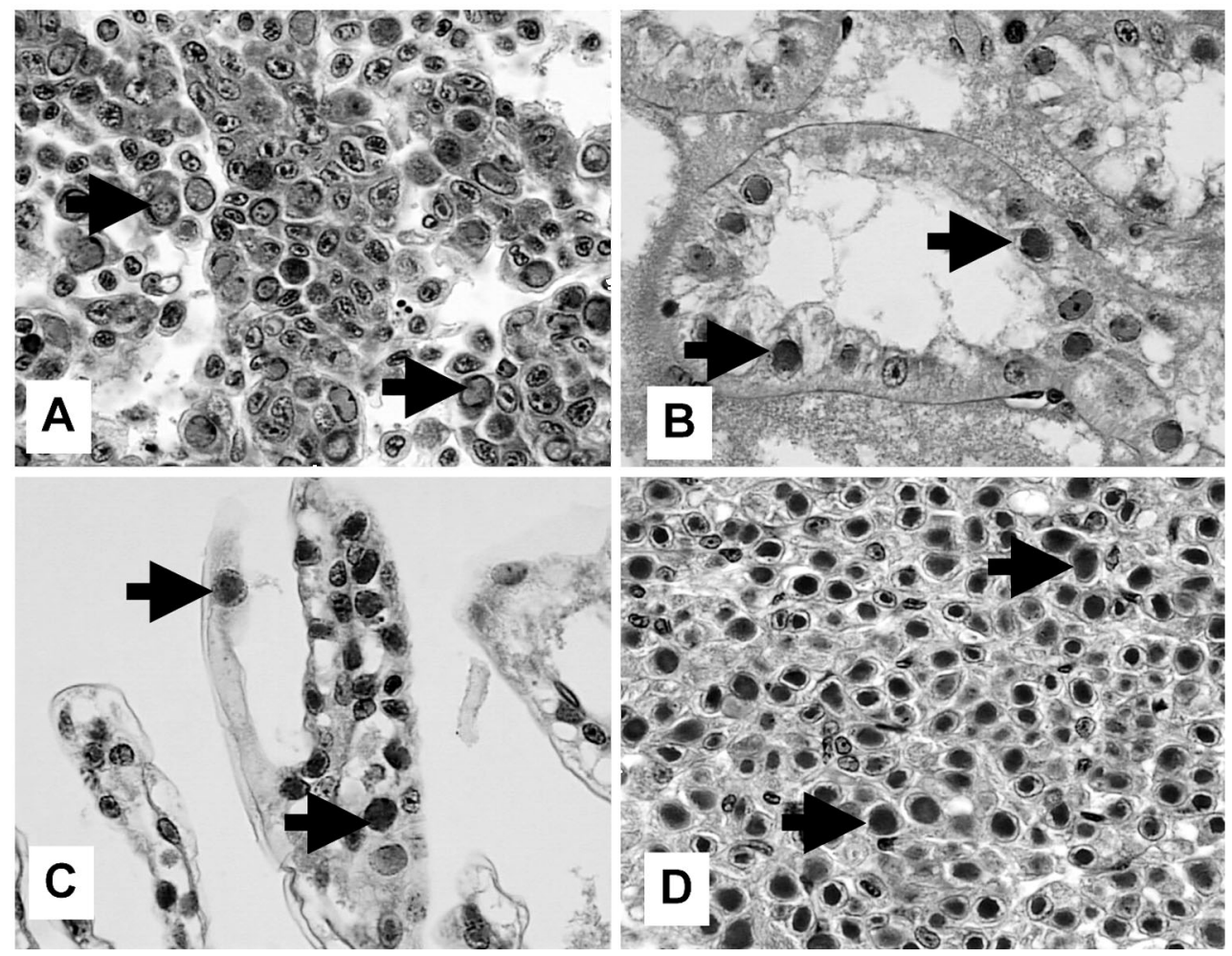

Fig. 5. Litopenaeus vannamei. WSSV intranuclear inclusion bodies (arrows) within tissues of moribund treatment-shrimp collected during Bioassays 1 and 2. (A) Hematopoieitic tissue; (B) antennal gland; (C) gill cuticular epithelium; (D) stomach cuticular epithelium. (600 $\times$ H \& E stain)

findings of WSSV among wild Litopenaeus setiferus and $F$. aztecus stocks originating from the coasts of Texas, Mississippi, South Carolina and Georgia over the past 10 y serve to document the presence of this virus in these marine environments, but not the source(s). In the current study, we have demonstrated that 2 of 20 boxes $(10 \%)$ of imported, frozen, whole green bait shrimp from China contained infectious WSSV. We believe that this is the first report of imported WSSV-infected shrimp being sold specifically for fresh and saltwater sport fishing in the US. and represents a direct route of penaeid shrimp virustransmission from the eastern into the western hemisphere. WSSV was initially detected by PCR analyses of the bait shrimp using 3 different primer sets. Virus viability was successfully demonstrated through injection-mediated infectivity bioassays, but not through per os challenge. The presence of widespread, WSSV, intranuclear inclusion bodies in the injected treatmentshrimp was confirmed by both routine histology and in situ hybridization analysis. Both WSSV-positive findings were for boxes containing wild caught Parapenaeopsis sp. from China. However, due to the degraded state of the tissues upon thawing (data not shown), we were unable to determine by either histopathology or in situ hybridization if these frozen shrimp were actively or subclinically infected. No viruses were detected by PCR in the 8 boxes of native GOM L. setiferus and Farafantepenaeus duorarum bait shrimp, nor in the 15 boxes of imported Metapenaeopsis sp. from China that were tested. The negative WSSV findings for these bait samples may be the result of inadequate sample size, natural species-specific resistance to WSSV (as previously determined for F. duorarum: Lightner et al. 1998), simple lack of WSSV infection among these shrimp, or possible seasonal occurrence of the disease among one or more of these species. The lack of detectable TSV or YHV/GAV may have been due to one or more of the above reasons, or a result of the degraded state of the RNA in the majority of our samples, as suggested by the poor beta-actin RT-PCR results obtained. The possibility that the RNA samples may have degraded during extraction has been considered and, as recommended for YHV RNA extractions (OIE 2003), we have since begun homogenizing tissues in TRIzol ${ }^{\circledR}$, with improved RNA recovery. Because of the small scope of our current study, a more extensive virus survey of both imported and native, frozen bait shrimp is warranted. 
Upon initiating this study, the first 16 boxes were thawed and frozen twice to collect pleopods for DNA extraction and (later) for RNA extraction. The 2 WSSVpositive boxes of bait shrimp were thawed on 2 additional occasions to prepare the treatment inoculums and minced tissues used in the 3 infectivity bioassays. Loss of virus viability due to multiple freeze-thaw cycles has been documented, with RNA viruses being more prone to inactivation than DNA viruses (Flegel \& Fegan 2002, Parker \& Martel 2002). However, no published information was found concerning the effect of multiple freeze-thaw cycles on WSSV viability, and this is an area for future investigation. The failure of the WSSV-positive bait shrimp to induce infection by oral challenge (Bioassay 3) may have been the result of virus inactivation due to multiple freeze-thaw cycles and consequent insufficient infectious dose. To eliminate thawing of frozen shrimp for PCR tissue-collection and preserve virus viability for later infectivity studies, a simple and rapid sampling method, using an electric drill, was tested. This method was employed to collect tissue samples for PCR analysis from the last 12 boxes of bait shrimp analyzed in this study, but which were found to be negative for WSSV, YHV/GAV, IHHNV and TSV. To test the validity of this sampling method, drill tailings were produced from the 2 WSSV-positive bait boxes and analyzed using the same 3 PCR assays for WSSV detection that were originally employed to test pooled pleopod samples. As with the pleopod samples, the PCR results of the drill tailings from both boxes of shrimp were WSSV-positive, indicating that this methodology holds promise for sampling frozen blocks of shrimp for disease-screening.

WSSV is known to infect $\sim 50$ different freshwater and marine crustacean species, and its lethality in shrimp is well documented (Flegel \& Fegan 2002). Repeated introduction of imported, WSSV-infected bait shrimp into both inland freshwater systems and marine environments poses a potential health risk to previously unexposed, susceptible indigenous crustacean populations and, indirectly, to both coastal shrimp farms and those aquatic species that are dependent on wild crustaceans as a food source. Further, there is a genuine risk that other exotic penaeid shrimp viral diseases, either currently known (i.e. YHV/GAV) or yet to emerge, may also be introduced into US waters by this route. In the US, shrimp farming is conducted using high-health Litopenaeus vannamei stocks (Wyban et al. 1992, Lotz et al. 1995, Lightner 2004). Stringent self imposed and state mandated biosecurity measures are followed by both hatcheries and farms to prevent potential pathogens from either gaining entrance or, in the event of an epizootic, from escaping into surrounding natural bodies of water (Berrigan 2002, Texas Administrative Code website: http://info.sos.state.tx.us/ pls/pub/read-
tac\$ext.ViewTAC?tac_view $=5 \& \mathrm{ti}=31 \& \mathrm{pt}=2 \& \mathrm{ch}=57 \& \mathrm{sch}$ $=\mathrm{A} \& \mathrm{rl}=\mathrm{Y}$ ). During 2004, an outbreak of WSSV on a farm in Hawaii and TSV epizootics on 5 separate farms in South Texas reopened the issue of the source(s) of these viral diseases and how they are entering the US. Various national workshops on shrimp viruses have identified imported postlarvae and broodstock, frozen imported commodity shrimp, imported, frozen bait-shrimp, ship ballast-water, shrimp packing-plant wastes, non-shrimp animal importations, escaped farmed shrimp and farm effluents as either potential or known sources of virus introduction (JSA 1997, Lightner 2002). However, regulations to prevent virus introduction or release into natural aquatic systems have only been directed towards the US shrimp mariculture industry to date and are mandated by individual states. The general consensus in Texas and by participants of the various shrimp virus workshops is that federal intervention is needed to address and prevent viral disease introduction by the other aforementioned pathways (JSA 1997). In Mexico, all frozen (uncooked) shrimp imports must either be accompanied by a PCR diagnostic report indicating that the shrimp are free of WSSV and $\mathrm{YHV}$, and/or tested for these viruses in Mexico prior to release for distribution. Shipments found to be WSSV or YHV-positive are then either returned to the country of origin or cooked to inactivate the viral pathogens (Galaviz-Silva 2000 and pers. comm.). In Australia, WSSV was identified as a pathogen of concern in relation to the importation of fresh-frozen, green shrimp by the Bureau of Resource Sciences (BRS) report on aquatic animal quarantine in Australia and the report by the National Task Force on Imported Fish and Fish Products provided to the Australian Department of Agriculture, Fisheries and Forestry (DAFF) in 1996. As an interim measure, fresh-frozen bait shrimp have been banned from entering Australia since 1996 pending completion of an import risk analysis of this product by Biosecurity Australia (Heard, DAFF, pers. comm.). More recently, YHV has also been recognized as a pathogen of concern. Prohibition of frozen bait-shrimp importation into Australia sets a precedent for managing this problem and provides one possible solution; 2 other options include mandatory PCR screening of imported bait shrimp to identify and eliminate virusinfected lots, or application of a yet-to-be-determined virus-inactivation procedure (gamma irradiation?) that will not adversely affect product quality or significantly increase bait-shrimp processing costs. Although the risk analysis conducted by Flegel \& Fegan (2002) indicated that bait shrimp pose a low risk of virus introduction in the case of Australia, they concluded that, in general, frozen products used as bait constitute a high risk of pathogen introduction as they are released directly into the aquatic environment. 
The GOM shrimp fishery, together with the Texas coastal shrimp farms, contribute $\sim 30 \%$ of the 200 million pounds (90 $703 \mathrm{mt}$ ) of shrimp annually produced in the US and are important Texas economic resources (G. Treece, Texas Sea Grant, pers. comm.). Currently, there are no federal regulations that require shrimpvirus screening of imported frozen shrimp destined for either sport fishing or human consumption in the US (P. Merrill, USDA/APHIS, pers. comm.). However, such regulations already exist in other shrimp producing countries (i.e. Australia, Brazil, Nicaragua, Colombia and Mexico), and a comprehensive review of these policies is needed to further aid US risk managers and stakeholders in evaluating this issue. Although we have demonstrated that bait shrimp are a route of viral disease introduction, it was beyond the scope and resources of the current study to evaluate the health risk posed by this product to indigenous and farmed crustaceans in Texas. This was, partly, due to a lack of available data concerning the annual quantity, sources and distribution of imported, frozen bait shrimp that are sold in this country (J. Ward, NOAA, pers. comm.) as well as the percentage of imports that are virusinfected. Complicating the issue further is that no restrictions exist to prevent anglers from purchasing and utilizing imported, consumable, frozen shrimp as bait. It is our hope that the findings of the current study will prompt a risk assessment of imported frozen bait shrimp by the US Department of Agriculture, Animal and Plant Health Inspection Service (APHIS).

Acknowledgements. The authors thank Mr. B. Rosenberry, Dr. T. Samocha, Dr. J. Y. Liu, Mr. G. Treece and Dr. I. K. Jang for their assistance with the identification of the imported bait shrimp from China; Drs. R. Heard and P. Beers (DAFF) for their comments and insights concerning Australia's shrimpimport regulations; Dr. E. Scura, Mr. H. Clifford and Mr. G. Jaramillo of Shrimp Improvement Systems for generously providing the SPF Litopenaeus vannamei used in the bioassays; Dr. S. Nates and Ms. C. Shew of Zeigler Bros. for kindly donating the feeds used in this study; and Dr. J. Reagor and Mr. L. Wadsworth of Texas A\&M University for photographic assistance.

\section{LITERATURE CITED}

Bell T, Lightner DV (1988) A handbook of normal penaeid shrimp histology. World Aquaculture Society, Baton Rouge, LA

Berrigan M (2002) State policies and regulations, Florida. In: Proceedings of the Shrimp Virus Disease Workshop. Nov 28-29, 2001, New Orleans, LA. National Marine Fisheries Service, Panama City Laboratory Contribution 02-05, Panama City, FL, p 16-17

CEI (2004a) White spot disease, United States, April 2, 2004, Impact worksheet. Animal Plant Health Inspection Service, US Department of Agriculture Veterinary Services. Fort Collins, CO. Also available at: http:// www.aphis.usda.gov/vs/ceah/cei/IW_2004_files/wsd_us_ 0404_files/wsd/_us_04004.htm

CEI (2004b) Taura syndrome virus, United States, June 16, 2004, Impact worksheet. Animal Plant Health Inspection Service, US Department of Agriculture Veterinary Services. Fort Collins, CO. Also available at: http:// www.aphis.usda.gov/vs/ceah/cei/IW_2004_files/tsv_tx_062 004_files/TSVTX062004.htm

Chang YS, Peng SE, Wang HC, Hsu HC and 5 others (2001) Sequencing and amplified restriction fragment length polymorphism analysis of ribonucleotide reductase large subunit gene of the white spot syndrome virus in blue crab (Callinectes sapidus) from American coastal waters. Mar Biotechnol 3:163-171

Chapman RW, Browdy CL, Savin S, Prior S, Wenner E (2004) Sampling and evaluation of white spot syndrome virus in commercially important Atlantic penaeid shrimp stocks. Dis Aquat Org 59:179-185

Cowley JA, Cadogan LC, Wongteerasupaya C, Hodgson RAJ, Boonsaeng V, Walker PJ (2004) Multiplex RT-nested PCR differentiation of gill-associated virus (Australia) from yellow head virus (Thailand) of Penaeus monodon. J Virol Methods 117:49-59

Dhar AK, Roux MM, Klimpel KR (2002) Quantitative assay for measuring the Taura syndrome virus and yellow head virus load in shrimp by real-time RT-PCR using SYBR green chemistry. J Virol Methods 104:69-82

Dore I, Frimodt C (1987) An illustrated guide to shrimp of the world. Osprey Books, Huntington, NY

Durand SV, Tang KF, Lightner DV (2000) Frozen commodity shrimp: potential avenue for introduction of white spot syndrome virus and yellow head virus. J Aquat Anim Health 12:128-135

Flegel TW, Fegan DF (2002) Strategies for preventing the spread of fish and shellfish diseases. Fish Sci 68 (Suppl) I: $776-788$

Galaviz-Silva L (2000) Virus del sindrome de Taura (TSV) y virus del sindrome de la mancha blanca (WSSV), agentes causantes de epizootias en la camaronicultura Mexicana (1996 - 1999). PhD dissertation, Universidad Autonoma de Nuevo Leon, Monterrey

Hasson KW, Lightner DV, Poulos BT, Redman RM, White BL, Brock JA, Bonami JR (1995) Taura syndrome virus (TSV) lesion development and the disease cycle in the Pacific white shrimp Penaeus vannamei. Dis Aquat Org 36:81-93

Hasson KW, Lightner DV, Mohney LL, Redman RM, Poulos BT, White BL (1999) Taura syndrome in Penaeus vannamei: demonstration of a viral etiology. Dis Aquat Org 23:115-126

Huang J, Song XL, Yu J, Yang CH (1994) Baculoviral hypodermal and hematopoietic necrosis-pathology of the shrimp explosive epidemic disease. Abstract. Yellow Seas Fisheries Institute, Qingdao

JSA (Joint Subcommittee on Aquaculture shrimp virus work group) (1997) An evaluation of potential shrimp virus impacts on cultured shrimp and wild shrimp populations in the Gulf of Mexico and southeastern US Atlantic coastal waters. National Marine Fisheries Service, Washington, DC. Also available at: http://www.nmfs.noaa.gov/trade/ jsash16.pdf

Kim CK, Kim PK, Sohn SG, Sim DS and six others (1998) Development of a polymerase chain reaction (PCR) procedure for the detection of baculovirus associated with white spot syndrome (WSBV) in penaeid shrimp J Fish Dis 21: $11-17$

Lightner DV (1996) A handbook of shrimp pathology and diagnostic procedures for diseases of cultured penaeid shrimp. World Aquaculture Society. Baton Rouge, LA 
Lightner DV (2002) Shrimp diseases and exotic pathogens. In: Proceedings of the Shrimp Virus Disease Workshop. Nov 28-29, 2001, New Orleans, LA. National Marine Fisheries Service, Panama City Laboratory Contribution 02-05, Panama City, FL, p 6-10

Lightner DV (2004) Biosecurity in shrimp farming: pathogen exclusion through use of SPF stock and routine surveillance. Aquaculture 36:229-248

Lightner DV, Redman RM, Poulos BT, Nunan LM, Mari JL, Hasson KW (1997) Risk of spread of penaeid shrimp viruses in the Americas by the international movement of live shrimp for aquaculture and frozen shrimp for commodity markets. Rev Sci Tech 16:146-160

Lightner DV, Hasson KW, White BL, Redman RM (1998) Experimental infection of western hemisphere penaeid shrimp with asian white spot syndrome virus and Asian yellow head virus. J Aquat Anim Health 10:271-281

Lo CF, Leu JH, Ho CH, Chen CH and 8 others (1996) Detection of baculovirus associated with white spot syndrome (WSBV) in penaeid shrimp using polymerase chain reaction. Dis Aquat Org 25:133-141

Lo CF, Ho CH, Chen CH, Liu KF and 8 others (1997) Detection and tissue tropism of white spot syndrome baculovirus (WSBV) in captured brooders of Penaeus monodon with a special emphasis on reproductive organs. Dis Aquat Org 30:53-72

Lotz J, Browdy CL, Carr WH, Frelier PF, Lightner DV (1995) USMSFP suggested procedures and guidelines for assuring the specific pathogen status of shrimp broodstock and seed. In: Browdy CL, Hopkins JS (eds) Proceedings of the special session on shrimp farming. World Aquaculture Society, Baton Rouge, LA, p 66-75

Loy JK, Frelier P, Varner P, Templeton JW (1996) Detection of the etiologic agent of necrotizing hepatopancreatitis in cultured Penaeus vannamei from Texas and Peru by polymerase chain reaction. Dis Aquat Org 25:117-122

Nunan LM, Poulos BT, Lightner DV (1998a) The detection of white spot syndrome virus (WSSV) and yellow head virus (YHV) in imported commodity shrimp. Aquaculture 160: 19-30

Nunan LM, Poulos BT, Lightner DV (1998b) Reverse tran-

Editorial responsibility: Timothy W. Flegel,

Bangkok, Thailand scription polymerase chain reaction (RT-PCR) used for the detection of Taura syndrome virus (TSV) in experimentally infected shrimp. Dis Aquat Org 34:87-91

OIE (Office International des Epizooties) (2003) Diagnostic manual for aquatic animal diseases, 4th edn. OIE, Paris

Ostrowski AC (2004) Consortium research update FY2004. The latest report from the USMSFP consortium December 2004. Waimanolo, HI, p 1-6. Also available at: http:// www.usmsfp.org/research.htm

Parker LV, Martel CJ (2002) Long-term survival of enteric microorganisms in frozen wastewater. In: Technical Report TR-02-16 of the U.S. Army Corps of Engineers, Engineer Research and Development Center, Cold Regions Research and Engineering Laboratory (ERDC/ CRREL). U.S. Army Corps of Engineers, Hanover, NH, p $1-65$

Prior S, Segars A, Browdy CL (2001) A preliminary assessment of live and frozen bait shrimp as indicators and/or vectors for shrimp viruses. In: Aquaculture 2001. Book of abstracts. World Aquaculture Society, Baton Rouge, LA

Richman LK, Montali RJ, Nichols DK, Lightner DV (1997) A newly recognized fatal baculovirus infection in freshwater crayfish. In: Baer CK (ed) Proceedings of the American Association of Zoo Veterinarians, Oct 26-30, Houston, TX, p 262-264

Sambrook J, Fritsch EF, Maniatis T (1989) Molecular cloning: a laboratory manual. Chapter 6, Gel electrophoresis of DNA. Cold Spring Harbor Laboratory Press, Plainview, NY

Tapay LM, Cesar E, Nadala B Jr, Loh PC (1999) A polymerase chain reaction protocol for the detection of various geographical isolates of white spot virus. J Virol Methods 82: $39-43$

Wyban JA, Swingle JS, Sweeney JN, Pruder GD (1992) Development and commercial performance of high health shrimp using specific pathogen free (SPF) broodstock Penaeus vannamei. In: Wyban JA (ed) Proceedings of the special session on shrimp farming. World Aquaculture Society, Baton Rouge, LA, p 254-259

Yu HP, Chan TY (1986) The illustrated penaeoid prawns of Taiwan. National Taiwan College of Marine Science and Technology, Southern Materials Center

Submitted: November 8, 2005; Accepted: January 12, 2006 Proofs received from author(s): July 17, 2006 